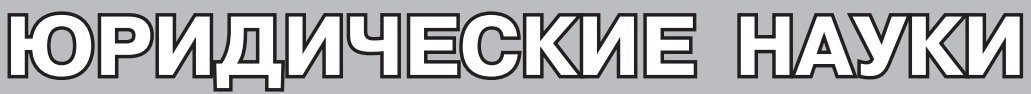

\section{Трансформация имиАжевого статуса угомовно-испоннитеАьной системы в контексте цикмического помитогенеза России}

\author{
И. А. ЕРМОЛАЕВ \\ Центр общественных связей ФСИН России, г. Москва, Российская Федерация \\ Научно-исследовательский институт ФСИН России, г. Москва, Российская \\ Федерация \\ e-mail: ErmolaevIA@admhmao.ru
}

\author{
А. Н. КОРОБОВ \\ Федеральная служба исполнения наказаний России, г. Москва, Российская \\ Федерация \\ e-mail: udmail@fsin.gov.ru
}

\section{В. Ю. ПАНЧЕНКО}

Правовое управление ФСИН России, г. Москва, Российская Федерация Научно-исследовательский институт ФСИН России, г. Москва, Российская Федерация

Красноярский государственный аграрный университет, г. Красноярск, Российская Федерация

ORCID: https://orcid.org/0000-0003-4822-7151, e-mail: panchenkovlad@mail.ru

\section{Л. А. ПЕТРУЧАК}

Московский государственный лингвистический университет, г. Москва, Российская Федерация

e-mail: lar-petruchak@yandex.ru

\section{P. А. РОМАШОВ}

Вологодский институт права и экономики ФСИН России, г. Вологда, Российская Федерация

Самарский национальный исследовательский университет им. академика С. П. Королева, г. Самара, Российская Федерация

ORCID: https://orcid.org/0000-0001-9777-8625, e-mail: romashov_tgp@mail.ru

Р е фер а т

Введение: являясь структурно-функциональным элементом государственного механизма (своего рода государством в государстве), тюремная система трансформируется вместе с ним. Соответственно, видоизменяется и имиджевый статус как самой тюрьмы, так и представителей тюремной власти и тюремного населения. Цель: провести комплексный анализ имиджевого статуса отдельных социальных систем на примере уголовно-исполнительной системы для выявления особенно- 
стей его формирования и способов оптимизации. Авторский коллектив актуализирует проблему понимания термина «система» при рассмотрении имиджевого статуса социальной системы в целом и уголовно-исполнительной системы в частности. Освещаются проблемы формирования смысловых образов и имиджевых статусов на примере трех социальных институтов (школа, армия, тюрьма), схожих с точки зрения параметрических характеристик и функционирования и качественно отличающихся имиджевым статусом. В статье всесторонне рассматривается биполярный имидж уголовно-исполнительной системы: с одной стороны, тюрьма неразрывно связывается с человеческой бедой, злом, к которому нельзя относиться положительно, с другой - будучи инструментом государственной правоохранительной политики, тюрьма гарантирует неотвратимость наказания за преступление, обеспечивая исполнение наказания, защищая правопослушных граждан, что является благом для общества и государства. Методы: комплексный и системный анализ, позволивший осуществить сравнение уголовно-исполнительной системы с другими общественными институтами на различных этапах политогенеза России. Результаты: особенности формирования и функционирования имиджевого статуса российской уголовно-исполнительной системы рассмотрены в контексте концепции циклического политогенеза. Согласно ей в истории единого российского государства следует выделять три цикла: имперский, советский, постсоветский. В рамках каждого из них Россия была представлена качественно отличающимися друг от друга формой государственного правления, хозяйственно-экономическим укладом, социальной структурой общества и др. В таких разных государствах существовали различные модели тюремных систем, формирование и функционирование которых (а равно и трансформация имиджевого статуса) осуществлялись как под воздействием государственной пенитенциарной политики, так и под влиянием общественного сознания (национального менталитета). Выводы: современное состояние уголовно-исполнительной системы можно охарактеризовать как переходное. Наряду с наследием советского прошлого в ней наблюдаются серьезные изменения, обусловленные демократизацией и гуманизацией в целом политико-правовой системы Российской Федерации. Трансформация имиджа системы исполнения наказаний направлена на повышение уровня ее открытости и формирование положительного мнения о ее деятельности. Важно, чтобы в общественном сознании имидж уголовно-исполнительной системы как преимущественно карательной постепенно сменился представлением о ней как системе пенитенциарной, ставящей на первое место «возрождение» через раскаяние и осознание преступником своей человеческой сущности. Что касается оптимизации имиджевого статуса сотрудников уголовно-исполнительной системы со стороны государства, то следует прежде всего уравнять их должностной статус с аналогичными статусами военнослужащих и сотрудников спецслужб, которые, как и представители тюремной системы, служат государству, однако находятся в более привилегированном положении. Повышение престижа службы в уголовно-исполнительной системе в глазах действующих либо потенциальных сотрудников предполагает отказ от такой дифференциации.Ключевые слова: имидж; имиджевый статус; трансформация имиджа; уголовно-исполнительная система; тюрьма; тюремная администрация; осужденные; каторга; закономерность; уголовное преследование; исполнение наказания; Концепция развития уголовно-исполнительной системы; теория права.

12.00.01 - Теория и история права и государства; история учений о праве и государстве.

Для цитирования: Ермолаев И. А., Коробов А. Н., Панченко В. Ю., Петручак Л. А., Ромашов Р. А. Трансформация имиджевого статуса уголовно-исполнительной системы в контексте циклического политогенеза России. Пенитенциарная наука, 2021, т. 15, № 3 (55), с. 467-480. DOI 10.46741/2686-9764-2021-15-3-467-480.

\title{
Transformation of the Image Status of the Penal System in the Context of the Cyclical Political Genesis of Russia
}

\author{
ILYAS A. ERMOLAEV \\ Center for Public Relations of FSIN Russia, Moscow, Russian Federation \\ Research Institute of FSIN Russia, Moscow, Russian Federation \\ e-mail: ErmolaevIA@admhmao.ru
}

НАУЧНО-ПРАКТИЧЕСКИЙ ЖУРНАЛ 
ALEKSANDR N. KOROBOV

adviser to the Director of FSIN Russia, Moscow, Russian Federation

e-mail: udmail@fsin.gov.ru

VLADISLAV YU. PANCHENKO

Legal Department of FSIN Russia, Moscow, Russian Federation

Research Institute of FSIN Russia, Moscow, Russian Federation, Krasnoyarsk State Agrarian University, Krasnoyarsk, Russian Federation

ORCID: https://orcid.org/0000-0003-4822-7151, e-mail: panchenkovlad@mail.ru

\title{
LARISA A. PETRUCHAK
}

Moscow State Linguistic University, Moscow, Russian Federation

e-mail: lar-petruchak@yandex.ru

\section{ROMAN A. ROMASHOV}

Vologda Institute of Law and Economics FSIN Russia, Vologda, Russian Federation Korolev Samara National Research University, Samara, Russian Federation

ORCID: https://orcid.org/0000-0001-9777-8625, e-mail: romashov_tgp@mail.ru

\author{
Abstract \\ Introduction: being a structural and functional element of the state mechanism (a kind
} of "state within the state"), the prison system is transforming along with it. Accordingly, the image status of the prison itself and representatives of "prison authorities" and "prison population" is also changing. We bring to the fore the problem of understanding the term "system" in the context of the image status of the social system in general and the penal system in particular. We highlight the formation of semantic images and image statuses on the example of three social institutions (school, army, prison), which are similar in terms of parametric characteristics and functioning and qualitatively different in image status. The article comprehensively examines the bipolar image of the penal system: on the one hand, prison is inextricably linked with human misfortune, an evil that cannot be treated positively; on the other hand, as an instrument of state law enforcement policy, the prison guarantees the inevitability of punishment for a crime, ensuring the execution of punishment, protecting law-abiding citizens, which is a good thing for society and the state. Research materials and methods: the features of formation and functioning of the image status of the Russian penal ("prison") system are considered in the context of the concept of cyclic political genesis. In accordance with this concept, in relation to the history of the unified Russian state, three cycles should be distinguished (imperial, Soviet, post-Soviet). Within the framework of each, Russia was represented by qualitatively different forms of state government, economic order, social structure, etc. At the same time, in such "different" Russian states, there were different models of prison systems, the formation and functioning of which, as well as the transformation of the image status, was carried out under the influence of state prison policy and under the influence of public consciousness (national mentality). Results: the current state of the Russian penal system can be described as transitional. Along with the legacy of the "Soviet past", we observe serious changes proceeding from democratization and humanization of the political and legal system of the Russian Federation. Transformation of the image of the penal system is aimed at increasing the level of openness and forming a positive opinion about the functioning of the penitentiary system (the Concept for development until 2030). It is important that in the public consciousness the image of the penal system as a predominantly punitive prison system gradually be replaced by the idea of it as a penitentiary system, which is concerned primarily with "revival of the essence of humanity" in a person through awareness and repentance. As for the image status of employees of the penal system, the state can optimize it first of all by equalizing their official status with that of military personnel and special services employees, who, like representatives of the prison system, serve the Russian state, but are in a privileged position in relation to them. Increasing the prestige of the service in the penal system in the eyes of actual or potential employees implies the rejection of such differentiation.

Ke y w o r d s : image; image status; image transformation; penal system; prison; prison administration; convicts; penal servitude; regularity; criminal prosecution; execution of punishment; Concept for development of the penal system, theory of law. 
12.00.01 - Theory and history of law and the state; history of the teachings of law and the state.

For citation: Ermolaev I.A., Korobov A.N., Panchenko V.Yu., Petruchak L.A., Romashov R.A. Transformation of the image status of the penal system in the context of the cyclical political genesis of Russia. Penitentiary Science, 2021, vol. 15, no. 3 (55), pp. 467-480. DOI 10.46741/2686-9764-2021-15-3-467-480.

\section{Системный имидж: выработка рабочего определения понятия}

Словом «имидж» (от англ. image - «образ», «изображение», «отражение») в русском языке обозначается «искусственно сформированное впечатление о субъекте или объекте с тем, чтобы у окружающих людей сложилось определенное психологическое его восприятие» [7]. Взяв за основу приведенную дефиницию, можно выделить признаки, характеризующие имидж:

- социальность: имидж представляет собой явление человеческой культуры, возникающее и существующее в неразрывной связи с миром человеческих (общественных) отношений;

- формальность: представляя собой внешне выраженную логическую умозрительную конструкцию, имидж предполагает закрепление в определенных относительно устойчивых формах общественного (индивидуального и коллективного) сознания и таким образом получает как официальное, так и неофициальное признание и оценку;

- инертность - устойчивость по отношению к внутренним и внешним факторам воздействия: будучи сформированным в общественном сознании, имидж, как правило, не претерпевает существенных изменений в исторической динамике;

- реформативность: имидж под влиянием субъективных факторов может изменяться, причем изменения могут быть как обратимыми, так и необратимыми.

Представляя собой оценочную категорию, имидж занимает достаточно важное место в системе двухмерной социальной дифференциации, подразделяющей всю совокупность общественных явлений и событий на две условные группы: позитивную (как отражение добра, справедливости, правомерности) и негативную (как отражение зла, несправедливости, противоправности).

Имиджевая характеристика во всех случаях носит системный характер и предполагает создание своего рода общественного реноме как внутри системы нахождения носителя имиджа, так и за ее пределами. При этом нормальной является ситуация имиджевой дихотомии, когда один и тот же субъект наделяется противоположными образами в различных имиджеобразующих средах. Нормально и то, что в рамках одной социальной среды может происходить изменение имиджа в направлении с позитивного на негативный и наоборот.

Ярким примером имиджевой дихотомии является противоположная оценка октябрьских событий 1917 г. в России со стороны победивших в революции и создавших государство нового исторического типа и тех, кто одномоментно из господствующего класса превратился в «обломки старого мира», подлежащие утилизации на «свалке истории».

Примером изменения имиджевой оценки является трансформация образа И. В. Сталина, который для царского правительства выступал в качестве политического экстремиста, во времена своего правления рассматривался как великий вождь советского народа, затем обличался как инициатор массовых репрессий по отношению к тому же советскому народу, а в настоящее время предстает как эффективный менеджер [13], с руководящей ролью которого связываются достижения советского государства в экономическом и техническом развитии, победа в Великой Отечественной войне, формирование мировой социалистической системы, успешно противостоявшей капиталистическому империализму, и т. п.

В качестве объектов имиджевой оценки могут выступать не только люди и коллективы, но и социальные явления и события, предметы живой и неживой природы. Так, в своем обращении к Федеральному Собранию Российской Федерации в 2021 г. президент России В. В. Путин для обозначения недружественной по отношению к Российской Федерации политики стран «коллективного Запада» во главе с США использовал метафорический образ Шерхана и Табаки - негативных героев «Книги джунглей» Р. Киплинга [2].

Рассмотрение имиджевого статуса социальной системы в целом и уголовно-ис- 
полнительной системы в частности 1 актуализирует проблему понимания термина «система», используемого в достаточно большом диапазоне смысловых контекстов. Коротко остановимся на тех толкованиях, которые представляются наиболее значимыми.

Система - совокупность взаимосвязанных материальных (вещных) и нематериальных (виртуальных) предметов, коммуникация которых носит упорядоченный характер и влечет наступление результатов, являющихся целью организации и функционирования системной конструкции (политическая система, правовая система).

Система - взаимосвязанные явления и события, характеризующие в целом определенный этап (тип) социально-культурного развития (рабовладельческая система, феодальная система, буржуазная (капиталистическая) система, социалистическая система).

Система - упорядоченная совокупность знаний об объективной (природа) и субъективной (культура) реальности (система образования, система науки).

Система - устройство технических изделий и механизмов; технология механических и социальных процессов; структура государственных учреждений и общественных организаций (хронометрия - система технического измерения времени, система государственной и муниципальной службы).

Отсутствие универсального представления о системе не означает невозможности выявления ее основополагающего ключевого признака, каковым, на наш взгляд, выступает закономерность. Любая система основана на закономерности, одновременно являясь ее продуктом и инструментом репродукции.

Начиная с античного периода в области научного познания складывается понимание того, что выявление всякой закономерности, а значит, и детерминируемой ею системы предполагает следующую последовательность:

- определение совокупности параметрических свойств и характеристик, необходимых и достаточных для образования взаимосвязи явлений и событий, в комплексе образующих закономерность;

\footnotetext{
${ }^{1}$ В рамках данной статьи понятия «уголовно-исполнительная система» и «тюремная система» будут рассматриваться в качестве синонимичных взаимозаменяемых категорий
}

- нахождение факторов, определяющих взаимную зависимость между выявленными явлениями и событиями;

- установление периодичности повторяемости, необходимой для детерминации чередующихся явлений и событий в качестве закономерных [1].

Исходя из вышесказанного, представляется возможным следующее определение: система - упорядоченная на основании закономерности совокупность элементов, взаимодействие которых направлено на достижение обусловленных закономерностями результативных последствий (целевых установок).

Из сформулированной дефиниции следует, что не цель определяет закономерность, а напротив, уже сложившаяся закономерность позволяет определить цель и задать формальные системные параметры материального либо виртуального предмета.

Системность - универсальное свойство как объективной, так и субъективной реальности. Однако если говорить об имиджевой оценке системных образований, равно как и о системном имиджевом статусе, то, безусловно, речь следует вести о субъективных системах, создаваемых субъектами общественных отношений и подверженных субъективному восприятию и осмыслению.

К примеру, если мы рассматриваем в качестве системы социальную историю, то в качестве объективной категории (как закономерность течения времени и детерминированного им процесса социальнокультурных изменений) она не зависит от субъективного восприятия и не может быть ни фальсифицирована, ни тем более изменена, поскольку нельзя изменить то, что в настоящий момент уже прошло, то есть закончилось. Вместе с тем, являясь результатом субъективного отношения со стороны тех, кого в истории (прежде всего национальной) интересуют преимущественно отдельные события и персоналии, значимые не столько в плане хроникальной достоверности, сколько в их интерпретационном, собственно имиджевом значении, описание исторических версий, реконструируемых отдельными авторами, заранее ангажированными на достижение определенных результатов, приобретает субъективный характер, по определению не претендует на объективность и беспристрастность. «Нельзя жить в обществе и быть свободным от него», - замечал В. И. Ленин. Нельзя формировать от- 
страненное отношение к системе, являясь ее внутренним составным элементом либо современником.

Имидж любой социальной системы во всех случаях субъективен и в большей степени определяется не ее функциональностью, а своего рода пиаром, основной и единственной функцией которого является внедрение в ценностный ряд какой-либо социальной группы информации о предмете пиар-кампании как идеальном (оптимальном) в ряду ценностей этой социальной группы, нужной ей для самоидентификации, в целях дальнейшего закрепления его мифологической парадигмы [4].

Образ социальной системы создается представителями той общественной группы, которой тот или иной имиджевый статус осознанно либо неосознанно воспринимается в качестве предпочтительного.

Школа, армия, тюрьма: проблемы формирования смысловых образов и имиджевых статусов

Как уже было сказано ранее, системность является объективным свойством любой сложно организованной реальности независимо от того, выражена она в материальных (вещных) либо виртуальных формах. В свою очередь, оценка систем и наделение их обусловленными оценочными суждениями носит субъективный характер.

Рассмотрим три очень похожих с точки зрения параметрических характеристик системы, которые в общественном сознании наделяются качественно отличающимися имиджевыми статусами: школу (для чистоты сравнительного анализа конкретизируем предмет сравнения и из всего обилия образовательных учреждений выберем школуинтернат), армию, тюрьму.

Если абстрагироваться от эмоционального представления о названных системных категориях, то они становятся если не идентичными, то по крайней мере достаточно сходными как по организации, так и по функциональным технологиям.

Прежде всего, назовем сходные характеристики названных социальных конструкций:

- наличие изолированной среды пребывания - интернат, тюрьма, казарма (воинская часть);

- корпоративная стратификация населения изолированной среды - постоянный (школьная администрация, учителя, тюремная администрация, командный состав, офицеры и генералы) и временный (ученики, заключенные, солдаты и сержанты срочной службы) состав;

- принудительное вовлечение временного состава в изолированную от «свободного мира» среду пребывания;

- установленный свыше срок нахождения в изолированной среде для временного состава (период школьного обучения, службы в армии, отбывания наказания в учреждениях уголовно-исполнительной системы);

- меры юридической ответственности (дисциплинарной, административной, уголовной) за нарушение правил внутреннего распорядка и самовольное покидание (побег, самовольная отлучка, дезертирство) изолированной среды временного пребывания;

- принудительный надзор и контроль постоянного состава за временным;

- осуществление функций профессиональной подготовки, воспитания, формирования корпоративной культуры (неслучайно все названные социальные среды в обиходе нередко называются школой жизни).

Говоря об отличительных чертах, следует в первую очередь выделить особенности межсубъектной коммуникации в соответствующих системах.

В школе это связь поколений отцов и детей, объединенных целевой установкой формирования «строителей позитивного будущего».

Армейский коллектив формируется из солдат и командиров, являющихся «товарищами, воинским братством». Традиция отдания воинского приветствия призвана символизировать корпоративную солидарность военнослужащих независимо от служебного статуса и места, занимаемого в армейской иерархии.

Основная задача военных - защищать Отечество от врага. Последний воспринимается не в качестве совокупности людей, обладающих комплексом естественных и позитивных прав, а как «живая сила противника», уничтожение которой при помощи различных средств и технологий не только носит узаконенный характер, но и рассматривается как проявление воинской доблести и героизма: «если враг не сдается, его уничтожают».

В качестве примера можно привести заявление министра обороны России С. К. Шойгу о том, что «российские войска в Сирии уничтожили более 133 тысяч боевиков, в 
том числе 4,5 тысячи из стран СНГ» [16]. И это притом, что в Сирии не действует режим военного или чрезвычайного положения, а значит, и не ведутся собственно военные действия.

Возвращаясь к проблеме имиджа вышеназванных систем, следует констатировать, что школа и армия наделяются в общественном сознании неизменным позитивным статусом и всегда ассоциируются с формами социального блага.

Уголовно-исполнительная

система государства, представленная в массовом сознании образом тюрьмы, столь же неизменно воспринимается в негативном контексте. При этом отрицательный образ тюрьмы переносится на всех ее обитателей - и тюремную администрацию, и осужденных (обвиняемых). Отношения между данными социальными группами носят перманентно конфликтный характер, обусловленный столкновением и противоборством двух регулятивно-охранительных систем - правовой и криминальной. Вместе с тем их нельзя рассматривать по аналогии с «правом войны», где, как уже было сказано, в ходе военных действий стороны отказываются от коммуникативной схемы «человек - человек», заменяя ее смысловой конструкцией «враг - враг». В тюрьме конфликтующие стороны представлены людьми, обладающими, несмотря на существенные ограничения, юридическими правами, реализация и защита которых должна обеспечиваться государством.

Получается, что, с одной стороны, государство принудительным образом человека в тюрьму сажает, а с другой - обязано обеспечивать ему определенный уровень безопасности и комфорта, который может быть условно обозначен как «минимум человеческого достоинства».

Из сказанного следуют два ключевых вывода. Во-первых, тюрьма всегда будет выступать в качестве системы с негативным статусом, поскольку ассоциируется в общественном сознании с проявлением социального зла, обусловленного феноменами преступления и преступности. Во-вторых, представляя собой изолированную социальную среду, объединяющую две перманентно конфликтующие группы, тюрьма тем не менее представляет мир человеческих отношений, в котором связи между тюремщиками и заключенными не допускают физического уничтожения и должны выстра- иваться с учетом сосуществования двух нормативных систем - правовой и криминальной.

\section{Имидж уголовно-исполнительной системы: проблемы отношения к тюрьме со стороны общества и государства}

Имидж уголовно-исполнительной системы - совокупность субъективных представлений, в комплексе образующих психологический образ уголовно-исполнительной системы (тюрьмы) в общественном сознании и определяющих ее место в системе государства и общества.

Аксиологический подход к пониманию государства и общества предполагает рассмотрение названных категорий в качестве дихотомичных комплексов, объединяющих противопоставляемые ценности, точнее, ценности и антиценности. В такой системе координат хорошему противостоит плохое, правдивому - ложное, правовому - преступное и т. п.

Как уже отмечалось, тюремная система в общественном сознании неразрывным образом связывается с феноменами преступления и преступности и воспринимается в качестве места содержания преступников.

Следует сразу оговориться, что такое представление есть не что иное как проявление так называемой обывательской, массовой культуры, оперирующей априорными категориями, основанными на таком универсальном аргументе, как «это всем известно».

В юридической науке и практике понятие «преступник» используется как метафорическое, обобщенное представление о лице, которое на различных стадиях реализации уголовно-правовой ответственности может выступать в качестве субъекта преступления, объекта оперативно-розыскной деятельности, подозреваемого, обвиняемого, подсудимого, осужденного, судимого и т. п.

Тюрьма не инициирует и не осуществляет уголовное преследование, не определяет виновность (невиновность) лица в совершении преступления, не решает вопросы срока и режима нахождения в местах лишения свободы. По сути, тюремная система представляет собой специализированное «хранилище» (место проживания - закрытое административно-территориальное образование) для людей, в отношении которых судом принято решение о применении нака- 
зания в виде изоляции от свободного общества на определенный временной срок либо пожизненно. Не тюрьма лишает человека свободы, но само ее название - место лишения свободы - предопределяет отношение к ней как к злому року, фатуму. Отсюда русская поговорка «От сумы и от тюрьмы не зарекайся», ибо и та, и другая беда может настичь каждого.

Кроме того, наличие такого вида наказания, как смертная казнь, обусловливает соотнесение тюрьмы и с данной мерой государственного принуждения.

Сравните имиджевый статус снайпера и палача. Представитель уважаемой военной профессии с гордостью говорит об уничтоженных врагах. Отношение к его деятельности со стороны государства выражено в наградах и почетных званиях. Ремесло палача независимо от характеристики лица, в отношении которого приводится в исполнение высшая мера, презираемо как недостойное занятие.

Получается, что в общественном сознании тюрьма неразрывным образом связывается с человеческой бедой, а беда - это всегда зло, к которому нельзя относиться так, как к добру.

Еще одна интересная деталь происходит из неразрывной связи тюрьмы и преступности. В национальном российском (русском) менталитете причудливым образом уживаются жесткое, если не сказать жестокое, отношение к лицам, подозреваемым и обвиняемым в совершении преступлений, и милосердие к «невольникам из тюремных застенков». С одной стороны, данные соцопросов свидетельствуют, что большинство опрошенных граждан ратуют за ужесточение уголовных наказаний, в том числе выступают за смертную казнь [15], с другой - опять-таки большинство россиян негативным образом воспринимают государственную тюремную систему, ассоциируя ее с узаконенным бесправием и массовыми нарушениями прав человека и гражданина.

Для государства тюремная система одна из структур, элемент правоохранительного механизма, инструмент легального принуждения, связанного с осуществлением уголовно-правовых санкций.

Отношение к тюрьме как механизму исполнения определенных государством наказаний (карательных мер) и одновремен- но системе исправления лиц, признанных виновными в совершении преступлений, возникает в мировой практике в эпоху Просвещения (XVII-XVIII вв.) с ее высокими идеалами гуманизма и естественного права. До этого тюрьмы в основном служили для досудебного содержания преступников, причем чаще всего весьма знатных. Основными видами наказания были пытки, увечья, позорные шествия и казни, смысл которых заключался не столько в наказании преступивших закон, сколько в демонстрации мощи государственной машины и насаждении осознания беспомощности по отношению к ней [14].

Просвещение, поставив во главу угла идею рациональности, обусловило формирование методологической дисциплины, предполагающей анализ и формализацию каждого действия, производимого человеком, подчинение этих действий как по отдельности, так и в их общей совокупности строгому порядку. Такое разложение действий на детали, выстраивание их в строгой последовательности, охватывающей большие промежутки времени, представляет собой отличный способ подчинения человека власти, будь то власть надсмотрщика, правителя или привычки. Поэтому дисциплинарное учреждение со строгим распорядком дня, возможностью постоянного надзора и контроля стало основным кандидатом на роль средства не только наказания, но и перевоспитания преступников с последующей их ресоциализацией в глобальном государственно организованном обществе, где аналогичным же образом действуют и другие ранее описанные институты - школа, армия и т. д. [14].

Являясь инструментом государственной правоохранительной политики, тюрьма должна занимать равное с другими государственными учреждениями положение.

Вместе с тем, если сравнить статус служащего уголовно-исполнительной системы со статусом военнослужащего либо сотрудника спецслужб, то становится очевидным, что отношение государства как к самой системе исполнения наказаний, так и к тем, кто в ней осуществляет государственное служение, выстраивается по так называемому остаточному принципу, что выражается в недостаточном материально-техническом обеспечении, меньших (по сравнению с другими государственными служащими) вознаграждениях и льготах. 
Особенности имиджевого статуса уголовно-исполнительной системы на различных этапах российского политогенеза

Являясь структурно-функциональным элементом государственного механизма, тюремная система трансформируется вместе с ним. Соответственно, видоизменяется и имиджевый статус как самой тюрьмы, так и представителей «тюремного населения».

Рассмотрение особенностей формирования и функционирования российской уголовно-исполнительной системы целесообразно осуществлять в контексте концепции циклического политогенеза [10].

В истории единого российского государства следует выделять три этапа (цикла), в рамках каждого из которых Россия была представлена качественно отличающимися друг от друга формами государственного правления (династическая империя, советская республика, президентская республика), хозяйственно-экономическим укладом, социальным структурированием общества и др. Два предшествующих цикла (имперский и советский) являются завершенными, постсоветский период носит длящийся характер. Для каждого цикла характерна собственная тюремная система. При этом неизменность общего негативного имиджа уголовно-исполнительной системы в общественном сознании не означает одинакового отношения к ней на различных этапах государственного развития.

В разных российских государствах существовали различные модели тюремных систем, формирование и функционирование которых (равно как и трансформация имиджевого статуса) осуществлялись под воздействием тюремной политики, содержание которой менялось в зависимости от направленности общегосударственной политики в целом.

Российская империя - государство, в экономическом отношении ориентированное на сельскохозяйственное производство, а также добычу и экспорт природных ресурсов. Основную часть подданных короны составляли крестьяне. Наиболее освоенными в социально-экономическом отношении территориями являлись западная и центральная части империи (Европейская Россия). Сибирь - это неевропейская часть империи за Уральским хребтом.

Сельскохозяйственная ориентированность социально-экономической системы, с одной стороны, обусловливала относительно невысокий (по сравнению с промышленно развитыми странами) уровень преступности, а с другой - определяла специфику организации тюремной системы:

- в городах, расположенных в европейской части, размещались тюремные замки и следственные изоляторы;

- основные массы осужденных следовали этапами в восточную часть страны.

Капитализация российской экономики во второй половине XIX в. имела оборотную сторону - резкий рост преступности и, как следствие, увеличение тюремного населения и расширение тюремной системы.

Отмечается, что количество осужденных за различные преступления в Российской империи с 1874 по 1912 г. утроилось. Если в 1874 г. обвинительный вердикт выносился в 58 тыс. случаев, то в 1912 г. было осуждено уже 180 тыс. чел. В начале $1870-х$ гг. на 100 тыс. чел. приходилось всего 50-90 осужденных, тогда как в начале 1910-х гг. - уже 150-200 [9].

Промежуточными пунктами размещения являлись пересыльные тюрьмы. В качестве окончательного места исполнения наказаний выступали населенные пункты, определенные под ссылку в каторжные работы и ссылку на поселение. Такое построение предполагало решение тюремной системой следующих функциональных задач:

- изоляция и максимальное удаление от имперских культурных центров социально опасных лиц;

- освоение «диких земель»;

- аккультурация местного («туземного») населения.

Особенностью российской тюремной системы рассматриваемого периода являлся сословный режим исполнения наказаний. М. Н. Гернет в своей «Истории царской тюрьмы» отмечает: «Всюду, во всех тюрьмах, для кого бы они ни предназначались, - отвратительно и тяжело... Но и сюда проникали классовые различия и давали себя знать, то отягчая, то облегчая положение заключенных. В этом отношении мы находим самые разительные примеры и знаем случаи, когда в одной и той же тюрьме одни страдали от голода, а другие составляли предмет величайшей заботы тюремной администрации, закармливавшей привилегированного заключенного дичью, соусами и пр. Эти фактические различия в положении отдельных заключенных в связи с их классовой при- 
надлежностью и их социальным положением имели место повсюду...» [3, с. 52].

Описанная классовая дифференциация тюремного положения осужденных, несомненно, негативным образом влияла на формирование имиджа тюрьмы в сознании угнетателей и угнетенных. Если для первых тюрьма являлась неприятным отступлением от привычной жизни «высшего света», которое, впрочем, не означало потерю ими привилегированного статуса, сохранявшегося и в местах заключения, то для последних тюремное заключение (ссылка, каторга), по сути, означало безысходность, попадание в прижизненный ад.

Подобное отношение достаточно образно описано в романе Д. В. Григоровича «Антонгоремыка», где главный герой, крепостной мужик Антон, проходит круг за кругом «земное чистилище» и в финале отправляется в сибирскую каторгу за несовершенное преступление, что знаменует собой полное бесправие и беззащитность простого человека перед произволом как отдельного чиновника (в романе - это управляющий барским имением Никита Федорович), так и государства в целом. Это мучительная смерть, пусть и отсроченная по времени.

Советская Россия в качестве основной инструментальной цели государственного строительства провозгласила курс на национализацию, индустриализацию и коллективизацию экономики, рассматривавшиеся идеологами государственно-правовой системы в качестве базиса социалистического строительства. Модернизация хозяйственной системы страны, связанная с переходом от сельскохозяйственной экономики к индустриальной, обусловила перестройку модели уголовно-исполнительной системы.

Если в Российской империи основные учреждения тюремной системы (за исключением тюремных замков) выносились за пределы крупных городов и находились в удалении от хозяйственно-промышленных центров страны, то в СССР исправительнотрудовые лагеря и колонии превратились в социально-производственные объекты, располагавшиеся в непосредственной близости от крупных заводов, строек, мест лесозаготовок и добычи полезных ископаемых и т. п. [5]. Участие осужденных в деятельности указанных объектов осуществлялось в рамках системы директивного планирования, оперировавшей в том числе установленной численностью рабочих рук, необходимых для воплощения в жизнь государственных планов социалистического строительства. Данным обстоятельством объясняется широкая практика применения наказания в виде лишения свободы по составам преступлений небольшой тяжести («колосковые» дела, дела, связанные с опозданием либо отсутствием на рабочем месте, и др.) в отношении представителей рабочего класса и крестьянства с тем, чтобы обеспечить наполняемость учреждений уголовно-исполнительной системы для выполнения спускаемых сверху планов.

Необходимость принудительного вовлечения в производственные отношения большого количества фактически бесплатной рабочей силы обусловила рост числа заключенных. Если на начальном этапе индустриализации и коллективизации в СССР в учреждениях уголовно-исполнительной системы содержалось около 200 тыс. чел. (1930 г. - 179 тыс., 1931 г. - 212 тыс.), то в предвоенный период их число уже превышало двухмиллионную отметку (1939 г. 2004 900), а в 1950 г. достигло исторического максимума - 2760095 чел. [8]. По состоянию на 1 марта 1940 г. ГУЛАГ состоял из 53 лагерей (включая лагеря, занятые железнодорожным строительством), 425 исправительно-трудовых колоний (в том числе 170 промышленных, 83 сельскохозяйственных и 172 контрагентских, то есть работавших на стройках и в хозяйствах других ведомств), объединяемых республиканскими, областными, краевыми отделами исправительнотрудовых колоний (ОИТК), и 50 колоний для несовершеннолетних [6].

Деятельность ГУЛАГа в указанный исторический период охватывала 17 отраслей народного хозяйства. Плановый объем товарной продукции составлял 2659,5 млн руб. Сотни восстановленных и построенных заново заводов и рудников, миллионы кубометров угля, леса, руды - все это выдавалось на-гора за счет фактически рабского труда заключенных [11, с. 133-134].

Из сказанного следует вывод, что в СССР механизм исполнения уголовного наказания одновременно рассматривался в качестве инструмента политической репрессии и реализации хозяйственной деятельности. При этом последнее функциональное направление со временем приобрело в советской тюремной индустрии приоритетное значение [10]. А. И. Солженицын писал: 
«Государству... нужна была рабочая сила: а) предельно дешевая, а лучше бесплатная; б) неприхотливая, готовая к перегону с места на место в любой день, свободная от семьи, не требующая ни устроенного жилья, ни школ, ни больниц...» [12, с. 94].

Имиджевый статус советской тюремной системы, сложившейся на этапе развитого социализма, не многим отличался от образа любого другого ЗАТО (закрытого административно-территориального образования), исключенного из системы общедоступной (массовой) информации, с той особенностью, что тюремное население, единожды попав за решетку, на всю оставшуюся жизнь поражалось в существенной части прав и свобод (прежде всего, запрет заниматься определенными видами деятельности и замещать соответствующие должности). Причем эти ограничения распространялись и на близких родственников бывших осужденных, что являлось прямым нарушением принципов законности, персонификации юридической ответственности, недопустимости применения повторного наказания за одно и то же преступление.

Тюремная система воспринималась рядовыми советскими гражданами как любая другая структура, связанная с легализованным государственным принуждением, по отношению к которой индивид предстает в качестве потенциально виновного субъекта. Отражением подобного отношения являлся достаточно известный и распространенный в советских правоохранительных органах циничный афоризм Ф. Э. Дзержинского: «Отсутствие у вас судимости - это не ваша заслуга, а наша недоработка».

Современная Россия, на конституционном уровне закрепив принцип правопреемства СССР (ст. 67.1 Конституции Российской Федерации), в структурном отношении фактически унаследовала советскую уголовноисполнительную систему - тюремно-колонистскую с отрядной формой размещения осужденных.

Концепция развития уголовно-исполнительной системы Российской Федерации до 2020 г., утвержденная распоряжением Правительства Российской Федерации от 14.10.2016 № 17725-р в своей содержательной части предусматривала:

- изменение видов исправительных учреждений для содержания осужденных в местах лишения свободы с фактическим прекращением их коллективного содержа- ния, постоянного пребывания в состоянии стресса, обусловленного необходимостью лавирования между требованиями администрации и основной массы осужденных;

- создание правовых и организационных условий для замены существующей системы исправительных учреждений на два основных вида - тюрьмы (общего, усиленного и особого режимов) и колонии-поселения (с обычным и усиленным наблюдением) - при сохранении учреждений, созданных для выполнения специальных задач: лечебноисправительных и лечебно-профилактических;

- разработку основанных на стандартах Европейских пенитенциарных правил моделей тюрьмы и колонии-поселения с учетом требований безопасности общества и персонала уголовно-исполнительной системы, а также необходимости реализации цели исправления осужденных.

Перепрофилирование большей части исправительных учреждений в тюрьмы общего, усиленного и особого режимов, а также создание новых колоний-поселений в соответствии с данной концепцией планировалось осуществить в 2012-2016 гг. Эти планы остались нереализованными. При этом вместо того, чтобы признать факт невыполнения концепции с последующими объективным разбором причин и определением средств и техники исправления допущенных ошибок и недоработок, тогдашнее руководство ФСИН России (ряд представителей которого, кстати, поменяли статус тюремных администраторов на положение осужденных) пошло по достаточно традиционному пути: «Если проблему нельзя решить, ее не следует обозначать».

Современная Концепция развития уголовно-исполнительной системы Российской Федерации на период до 2030 г., утвержденная распоряжением Правительства Российской Федерации от 29.04.2021 № 1138, носит обобщенный характер и оперирует терминологическими конструкциями «гуманизация условий отбывания наказаний и мер пресечения», «совершенствование правового регулирования в сфере реализации мер пресечения и исполнения уголовных наказаний с учетом международных обязательств Российской Федерации и общепризнанных норм международного права», «обеспечение исполнения наказания в условиях, не унижающих человеческого достоинства, соответствующих законодательству 
Российской Федерации и международным стандартам; совершенствование организации деятельности уголовно-исполнительной системы и т. п.», не привязанными к конкретным, подлежащим оценке результатам и срокам.

В обозначенном смысловом контексте не имеют особого значения указанные в названиях концептуальных актов конечные календарные даты (2020, 2025, 2030 гг.), поскольку пределов совершенствования чего бы то ни было (и тюремная система исключением не является), как известно, не существует.

Сегодняшнее состояние российской уголовно-исполнительной системы можно охарактеризовать как переходное. Как уже отмечалось, в структурном плане имеет место наследие советского прошлого. Вместе с тем ошибочно будет говорить о том, что нынешняя пенитенциарная система представляет собой клон советской тюрьмы.

Основными функциями уголовно-исполнительной системы становятся: срочное либо бессрочное (пожизненное) изолированное содержание лиц, представляющих повышенную общественную опасность; профилактика пенитенциарного и постпенитенциарного рецидива; исправительноресоциализационная функция, сутью которой является возвращение в свободное общество человека, осознавшего свою вину и раскаявшегося в ней, стремящегося жить среди людей по нормальным законам.

Поставленные цели предполагают в том числе трансформацию имиджа ведомства, направленную на «повышение уровня открытости и формирование положительного мнения о деятельности пенитенциарной системы». При этом очень важно, чтобы в общественном сознании имидж уголовноисполнительной системы как преимущественно карательной системы, постепенно сменился представлением о ней как о системе пенитенциарной, ставящей на первое место возрождение через раскаяние и осознание человеком собственной человеческой сущности, а сделать это можно только в том случае, если к людям, отбывающим наказание, будут относится по-человечески.

Имиджевая трансформация статуса российской уголовно-исполнительной системы предполагает изменение отношения к ней со стороны как общества, так и государства. При этом не следует заблуждаться и вставать на путь правового инфантилизма и идеализма, полагая, что возможно за от- носительно короткое время заменить негативный имидж на позитивный. Выше уже отмечалось, что у всех народов, во все времена тюремная система ассоциировалась, ассоциируется и будет ассоциироваться с человеческим злом, а это означает, что ее имидж всегда будет носить негативный характер.

Вместе с тем, не ставя перед собой невозможную задачу трансформации зла в добро, можно и нужно стремиться к рационализации зла, связанного с тюрьмой, с тем чтобы, осознавая его и ее объективный характер, постараться минимизировать вредоносное значение, по возможности компенсировав его социальными благами, которых, как это ни парадоксально звучит, в современной тюремной системе также немало. Речь, в первую очередь, идет о социальных функциях, выполняемых уголовно-исполнительной системой в отношении представителей общественных низов, составляющих значительную часть тюремного населения.

Уход от демонизации тюремного имиджа должен означать отказ от рассмотрения судимости, равно как и факта прекращения уголовного преследования по нереабилитирующим обстоятельствам, в качестве своеобразного информационного клейма, сопровождающего ранее судимого (освобожденного от уголовной ответственности по нереабилитирующим обстоятельствам) гражданина (а в ряде случаев и его ближайших родственников) в течение всей последующей жизни и серьезным образом ограничивающего его правовой статус.

Оптимизация имиджа сотрудников уголовно-исполнительной системы со стороны государства предполагает выравнивание их статуса (должностных окладов, надбавок, льгот) с аналогичными статусами военнослужащих и сотрудников спецслужб, которые так же, как и представители системы исполнения наказаний, служат России. Однако почему-то государство считает их службу приоритетной, что нередко приводит к фактическому разделению на привилегированную государственную службу и службу второго сорта. Если государство в лице своего аппарата хочет в реальности поднять престиж службы в уголовно-исполнительной системе, такая дифференциация должна быть преодолена.

И последнее. В свое время Петр Великий сформулировал: «Тюрьма есть ремесло окаянное, а потому исполнять его должны люди 
твердые, добрые и веселые». Полагаем, что в этой формуле содержится вневременной имиджевый код государственной уголовноисполнительной системы, которая никогда не будет популярной ни в одной из социаль- ных групп, образующих народонаселение любой страны, но без которой ни одно из государств, в том числе и Российская Федерация, не мыслит себя в обозримой и необозримой исторической перспективе.

\section{СПИСОК ЛИТЕРАТУРЫ}

1. Агошкова, Е. Б. Эволюция понятия системы / Е. Б. Агошкова, Б. В. Ахлибининский // Вопросы философии. 1998. - № 7. - С. 170-179.

2. «Вокруг Шерхана крутятся Табаки»: Путин высмеял задирающие Россию страны // PИA Новости : сайт. - URL: https://ria.ru/20210421/kipling-1729267652.html (дата обращения: 12.08.2021).

3. Гернет, М. Н. История царской тюрьмы. В 5 томах. Том 1. 1762-1825 / М. Н. Гернет. - Москва : Гос. изд-во юрид. лит., 1960. - 384 с

4. Глава 4. Концепт PR // Анализ языковой личности Всеволода Богданова : реферат. - URL: https://studbooks. net/733820/zhurnalistika/glava_kontsept (дата обращения: 12.08.2012).

5. Должиков, Р. С. Роль ГУЛАГа в экономике СССР / Р. С. Должиков // Инновационная экономика : материалы II Международной научной конференции (г. Казань, октябрь 2015 г.). - Казань : Бук, 2015. - С. 12-14.

6. Земсков, В. Н. Документы трагического времени: архивы открывают тайны. «Архипелаг ГУлАГ»: глазами писателя и статистика / В. Н. Земсков // Аргументы и факты. - 1989. - 11 ноября (№ 45). - URL: https://aif.ru/gazeta/ number/21150 (дата обращения: 12.08.2021).

7. Имидж: что это такое, как его создать и как изменить // VPLATE : сайт. - URL: https://vplate.ru/imidzh/sozdat-iliizmenit (дата обращения: 12.08.2021).

8. Количество и качество заключенных при Сталине, в РФ и США сегодня // LiveJournal. - URL: https://mikle1. livejournal.com/794911.html (дата обращения: 12.08.2021).

9. Количество осужденных в Российской империи утроилось с 1874 по 1912 годы // Livelnternet. - URL: https://www. liveinternet.ru/users/bolivarsm/post345518927/ (дата обращения: 12.08.2021).

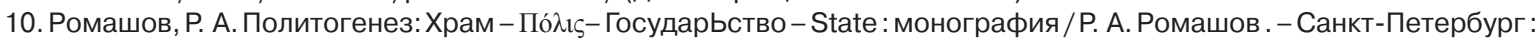
Алетейя, 2020. - 300 с. - ISBN 978-5-907189-93-5.

11. Смыкалин, А. С. Колонии и тюрьмы в Советской России / А. С. Смыкалин. - Екатеринбург : УрГЮА, 1997. 364 c. - ISBN 5-7845-0024-4.

12. Солженицын, А. И. Архипелаг ГУЛАГ. В 3 томах. Том 2 / А. И. Солженицын. - Москва : Новый мир, 1990. - 636 с. 13. Филиппов, А. В сто первый раз «об эффективном менеджере И. В. Сталине» / Александр Филиппов // СвободнаяПресса : сайт. - URL: https://svpressa.ru/blogs/article/110256/ (дата обращения: 12.08.2021).

14. Финиарель, А. Почему тюремное заключение не работает / Александр Финиарель // SCIENCEPOP : сайт. - URL: https://sciencepop.ru/pochemu-tyuremnoe-zaklyuchenie-ne-rabotaet/ (дата обращения: 12.08.2021).

15. ФОМ: смертную казнь считают допустимой 69 \% россиян // Коммерсантъ : сайт. - URL: https://www.kommersant. ru/doc/4147619 (дата обращения: 12.08.2021).

16. Шойгу заявил о разгроме ИГ в Сирии // РИА Новости : сайт. - URL: https://ria.ru/20200930/siriya-1577973755. html (дата обращения: 12.08.2021).

\section{REFERENCES}

1. Agoshkova E.B., Akhlibininskii B.V. Evolution of the term "system". Voprosy filosofii=Issues of Philosophy, 1998, no. 7 , pp. 170-179. (In Russ.).

2. "Vokrug Sherkhana krutyatsya Tabaki": Putin vysmeyal zadirayushchie Rossiyu strany [Tabakis are circling around Shere Khan: Putin ridiculed the countries that bully Russia]. Available at: https://ria.ru/20210421/kipling-1729267652.html (accessed August 12, 2021). (In Russ.).

3. Gernet M.N. Istoriya tsarskoi tyur'my. V pyati tomakh. T. 1. 1762-1825 [History of the Tsar's prison. In five volumes. Vol. 1. 1762-1825.]. Moscow: Gos. izd-vo yurid. lit. 1960. P. 52.

4. Glava 4. Kontsept PR [Chapter 4. The concept of PR]. Available at: https://studbooks.net/733820/zhurnalistika/glava kontsept (accessed August 12, 2021).

5. Dolzhikov R.S. The role of the GULAG in the Soviet economy. In: Innovatsionnaya ekonomika: Materialy II Mezhdunar. nauch. konf. (g. Kazan', okt. 2015 g.) [Innovation economy: proceedings of the second international research conference (Kazan, October 2015).]. Kazan: Buk, 2015. Pp. 12-14. (In Russ.).

6. Zemskov V.N. Documents of the tragic time: archives reveal secrets. "The Gulag Archipelago": through the eyes of a writer and statistics. Argumenty i fakty=Arguments and Facts, 1989, November 11, no. 45. Available at: https://aif.ru/ gazeta/number/21150 (accessed August 12, 2021). (In Russ.).

7. Imidzh: chto eto takoe, kak ego sozdat' $i$ kak izmenit' [Image: what it is, how to create it and how to change it]. Available at: https://vplate.ru/imidzh/sozdat-ili-izmenit/ (accessed August 12, 2021).

8. Kolichestvo i kachestvo zaklyuchennykh pri Staline, $v$ RF i SShA segodnya [The quantity and quality of prisoners under Stalin in Russia and the USA today]. Available at: https://mikle1.livejournal.com/794911.html (accessed August 12, 2021). 9. Kolichestvo osuzhdennykh v Rossiiskoi imperii utroilos's 1874 po 1912 gody [The number of convicts in the Russian Empire tripled from 1874 to 1912]. Available at: https://www.liveinternet.ru/users/bolivarsm/post345518927/ (accessed August 12, 2021).

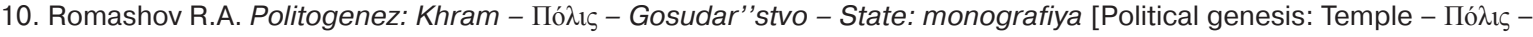
Государьство - State: monograph.]. Saint Petersburg: Aletei ya, 2020. 300 p.

11. Smykalin A.S. Kolonii i tyur'my v Sovetskoi Rossii [Colonies and prisons in Soviet Russia]. Yekaterinburg: Izd-vo UrGYuA, 1997. Pp. 133-134.

12. Solzhenitsyn A.I. Arkhipelag GULAG [The Gulag Archipelago]. Moscow, 1990. Vol. 2. P. 94. 
13. Filippov A. V sto pervyi raz "ob effektivnom menedzhere I.V. Staline" [For the umpteenth time about an effective manager Joseph Stalin]. Available at: https://svpressa.ru/blogs/article/110256/ (accessed August 12, 2021).

14. Finiarel' A. Pochemu tyuremnoe zaklyuchenie ne rabotaet [Why doing one's time doesn't work]. Available at: https:// sciencepop.ru/pochemu-tyuremnoe-zaklyuchenie-ne-rabotaet/ (accessed August 12, 2021).

15. FOM: smertnuyu kazn' schitayut dopustimoi $69 \%$ rossiyan [FOM: the death penalty is considered acceptable by $69 \%$ of Russians]. Available at: https://www.kommersant.ru/doc/4147619 (accessed August 12, 2021).

16. Shoigu zayavil o razgrome IG v Sirii [Shoigu said the ISIS in Syria is defeated]. Available at: https://ria.ru/20200930/ siriya-1577973755.html (accessed August 12, 2021).

\section{CВЕДЕНИЯ ОБ АВТOPAX / INFORMATION ABOUT THE AUTHORS}

ИЛЬЯС АБДУСАЛАМОВИЧ ЕРМОЛАЕВ - КаНДИДаТ философских наук, начальник Центра общественных связей ФСИН России, г. Москва, Российская Федерация; ведущий научный сотрудник НИИ ФСИН России, г. Москва, Российская Федерация, e-mail: ErmolaevIA@ admhmao.ru

АЛЕКСАНДР НИКОЛАЕВИЧ КОРОБОВ - СОВеТНИК ДИректора ФСИН России, г. Москва, Российская Федерация, e-mail: udmail@fsin.gov.ru

ВЛАДИСЛАВ ЮРЬЕВИЧ ПАНЧЕНКО - ДОКТОР ЮрИДИческих наук, начальник Правового управления ФСИН России, г. Москва, Российская Федерация; главный научный сотрудник НИИ ФСИН России, г. Москва, Российская Федерация; профессор кафедры теории и истории государства и права Красноярского государственного аграрного университета, г. Красноярск, Российская Федерация, ORCID: https://orcid.org/0000-0003-48227151, e-mail: panchenkovlad@mail.ru

ЛАРИСА АНАТОЛЬЕВНА ПЕТРУЧАК - ДОКТОр ЮрИДИческих наук, заведующий кафедрой общетеоретических правовых дисциплин, проректор по образовательной деятельности Московского государственного лингвистического университета, г. Москва, Российская Федерация, e-mail: lar-petruchak@yandex.ru

РОМАН АНАТОЛЬЕВИЧ РОМАШОВ - ДОКТОр ЮрИДИческих наук, профессор, заслуженный деятель науки Российской Федерации, профессор кафедры государственно-правовых дисциплин юридического факультета Вологодского института права и экономики ФСИН России, г. Вологда, Российская Федерация; профессор кафедры уголовного права и криминологии Самарского национального исследовательского университета им. академика С. П. Королева, г. Самара, Российская Федерация, ORCID: https://orcid.org/0000-0001-9777-8625, e-mail: romashov_tgp@mail.ru
ILYAS A. ERMOLAEV - Candidate of Sciences (Philosophy), Head of the Center for Public Relations of FSIN Russia, Moscow, Russian Federation, leading researcher at the Research Institute of FSIN Russia, Moscow, Russian Federation, e-mail: ErmolaevlA@admhmao.ru

ALEKSANDR N. KOROBOV - adviser to the Director of FSIN Russia, Moscow, Russian Federation, e-mail: udmail@ fsin.gov.ru

VLADISLAV YU. PANCHENKO - Doctor of Sciences (Law), Head of the Legal Department of FSIN Russia, Moscow, Russian Federation, Chief Researcher at the Research Institute of FSIN Russia, Moscow, Russian Federation, professor of the Department of Theory and History of State and Law at Krasnoyarsk State Agrarian University, Krasnoyarsk, Russian Federation, ORCID: https://orcid. org/0000-0003-4822-7151, e-mail: panchenkovlad@ mail.ru

LARISA A. PETRUCHAK - Doctor of Sciences (Law), Head of the Department of General Theoretical Legal Disciplines, Vice-Rector for Education of Moscow State Linguistic University, Moscow, Russian Federation, e-mail: lar-petruchak@yandex.ru

ROMAN A. ROMASHOV - Doctor of Sciences (Law), Professor, Honored Scientist of the Russian Federation, professor of the Department of State and Legal Disciplines at Faculty of Law of Vologda Institute of Law and Economics FSIN Russia, Vologda, Russian Federation, professor of the Department of Criminal Law and Criminology at Korolev Samara National Research University, Samara, Russian Federation, ORCID: https://orcid.org/0000-0001-97778625, e-mail: romashov_tgp@mail.ru

Статья поступила 16.08.2021 